\title{
Article \\ Characterization of a Novel Bacteriophage Henu2 and Evaluation of the Synergistic Antibacterial Activity of Phage-Antibiotics
}

\author{
Xianghui Li ${ }^{1}$, Tongxin $\mathrm{Hu}^{1}{ }^{1}$, Jiacun Wei ${ }^{1}$, Yuhua $\mathrm{He}^{1}{ }^{1}$, Abualgasim Elgaili Abdalla ${ }^{2} \mathbb{D}$, Guoying Wang ${ }^{1, *}$, \\ Yanzhang $\mathrm{Li}^{1}$ and Tieshan Teng ${ }^{1, *}$ \\ 1 Institute of Biomedical Informatics, School of Basic Medical Sciences, Henan University, Kaifeng 475004, \\ China; 10190158@vip.henu.edu.cn (X.L.); 1819010169@vip.henu.edu.cn (T.H.); \\ 1819010208@vip.henu.edu.cn (J.W.); 1819010160@vip.henu.edu.cn (Y.H.); 10190115@vip.henu.edu.cn (Y.L.) \\ 2 Department of Clinical Laboratory Sciences, College of Applied Medical Sciences, Jouf University, \\ Sakaka 2014, Saudi Arabia; aealseddig@ju.edu.sa \\ * Correspondence: 10190014@vip.henu.edu.cn (G.W.); Tengtieshan@vip.henu.edu.cn (T.T.)
}

check for updates

Citation: Li, X.; Hu, T.; Wei, J.; He, Y.; Abdalla, A.E.; Wang, G.; Li, Y.; Teng,

T. Characterization of a Novel

Bacteriophage Henu2 and Evaluation of the Synergistic Antibacterial Activity of Phage-Antibiotics. Antibiotics 2021, 10, 174. https:// doi.org/10.3390/antibiotics10020174

Academic Editors:

Barbara Dolegowska and

Adelaide Almeida

Received: 7 December 2020

Accepted: 7 February 2021

Published: 9 February 2021

Publisher's Note: MDPI stays neutral with regard to jurisdictional claims in published maps and institutional affiliations.

Copyright: (c) 2021 by the authors. Licensee MDPI, Basel, Switzerland. This article is an open access article distributed under the terms and conditions of the Creative Commons Attribution (CC BY) license (https:/ / creativecommons.org/licenses/by/ $4.0 /)$.

\begin{abstract}
Staphylococcus aureus phage Henu2 was isolated from a sewage sample collected in Kaifeng, China, in 2017. In this study, Henu2, a linear double-stranded DNA virus, was sequenced and found to be $43,513 \mathrm{bp}$ long with $35 \% \mathrm{G}+\mathrm{C}$ content and 63 putative open reading frames (ORFs). Phage Henu2 belongs to the family Siphoviridae and possesses an isometric head (63 $\mathrm{nm}$ in diameter). The latent time and burst size of Henu2 were approximately $20 \mathrm{~min}$ and 7.8 plaque forming unit (PFU)/infected cells. The Henu2 maintained infectivity over a wide range of temperature $\left(10-60{ }^{\circ} \mathrm{C}\right)$ and $\mathrm{pH}$ values (4-12). Phylogenetic and comparative genomic analyses indicate that Staphylococcus aureus phage Henu2 should be a new member of the family of Siphoviridae class-II. In this paper, Phage Henu2 alone exhibited weak inhibitory activity on the growth of $S$. aureus. However, the combination of phage Henu2 and some antibiotics or oxides could effectively inhibit the growth of $S$. aureus, with a decrease of more than three logs within $24 \mathrm{~h}$ in vitro. These results provide useful information that phage Henu2 can be combined with antibiotics to increase the production of phage Henu2 and thus enhance the efficacy of bacterial killing.
\end{abstract}

Keywords: Staphylococcus aureus; bacteriophage; phage-antibiotic synergy

\section{Introduction}

Staphylococcus aureus is a Gram-positive cocci bacterium commonly isolated from the skin and nostrils of approximately one-third of the global population [1]. It is the leading cause of wound infection ranging from mild skin infection to severe soft tissue infection potentially resulting in severe metastatic infection [2]. Since the $1940 \mathrm{~s}$, S. aureus has developed resistance to numerous antibiotics in clinical use. The bacterium employs multiple strategies to escape from antibiotics including deactivation of antibiotics by releasing enzymes including $\beta$-lactamases and shifting of drug-target such as alteration of penicillin-binding proteins (PBP) into $\mathrm{PBP} 2 \mathrm{a}$, a major mechanism of resistance to $\beta$-lactam antibiotics [3,4]. An increasing prevalence of methicillin-resistant S. aureus (MRSA) is one of the major global public health concerns [5,6]. Dissemination of MRSA with multi-resistance phenotypes has significantly caused limited treatment options of $S$. aureus infections $[7,8]$. As such, it is urgently essential to explore non-antibiotic approaches for the treatment of S. aureus infections.

Bacteriophages are ancient enemies of bacteria shown to exhibit natural antibacterial benefits [9-11]. They are extremely ubiquitous in nature, with an estimated order of $10^{31}$ [12], demonstrating clinical potential as therapeutic agents for the topical or nonsystemic treatment of bacterial infections [13]. Despite their therapeutic potential major 
shortcomings remain on the emergence of bacteriophage resistance. Recent novel approaches have been proposed to resolve the main problem of using phages, including phage cocktails and phage-antibiotic combinations [14,15]. Despite many studies showing that phage cocktail therapy exhibits an effective antibacterial effect and prevents the emergence of phage resistance, the single bactericidal mechanism and the need for largescale screening of different bacteriophages have limited its application [16-19]. Notably, phage-antibiotic synergy (PAS) is a phenomenon where a sub-inhibitory concentration of antibiotics enhances phage induced host cell decline. Due to their different bactericidal mechanisms and the limitation in the evolution of common resistance, (PAS) has shown a better bactericidal activity [20-22]. At the same time, phage-antibiotic synergy is used to combat drug-resistant bacteria, including multidrug-resistant, extensively-drug resistant, or pan drug-resistant bacteria [23-26]. Moreover, PAS has shown potential in different bacteria, including Pseudomonas aeruginosa, Escherichia. coli, Klebsiella. Pneumoniae, and Burkholderia cepacian by different phage-antibiotic combinations [27-33]. Limited reports have confirmed the synergistic effect of phages and antibiotics against S. aureus [34-38]. Nonetheless, existing data are scarce as well as inconsistent, and the activity of important groups of antibiotics remains underexplored in combination with S. aureus phages [39]. As such, this study evaluated the efficacy of subinhibitory concentrations of antibiotics (Clarithromycin, Linezolid, Cefotaxime, Tetracycline and Ciprofloxacin) and hydrogen peroxide combined with the phage Henu2 from the Siphoviridae family geared towards examining the ability of phage-antibiotic synergy in the killing of $S$. aureus.

\section{Results}

\subsection{Isolation and Morphology}

Phage Henu2 was isolated from sewage water using S. aureus N315 as a host [40]. Henu2 has an isometric head with a width of $63 \mathrm{~nm}$ in diameter and a tail with a length of $186 \mathrm{~nm}$ long (Figure 1A). The baseplate structure of the phage Henu2 comprised multiple disc baseplates similar to that of phage SA97 [41]. Notably, Henu2 belongs to the genus Phietavirus in the family of Siphoviridae [42].

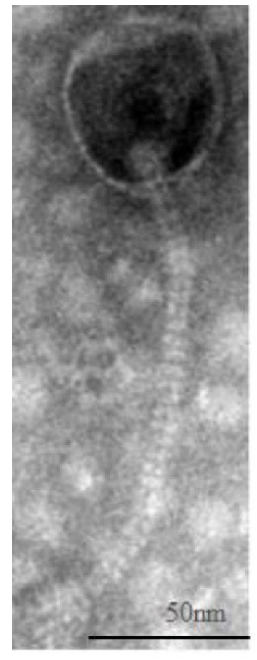

A

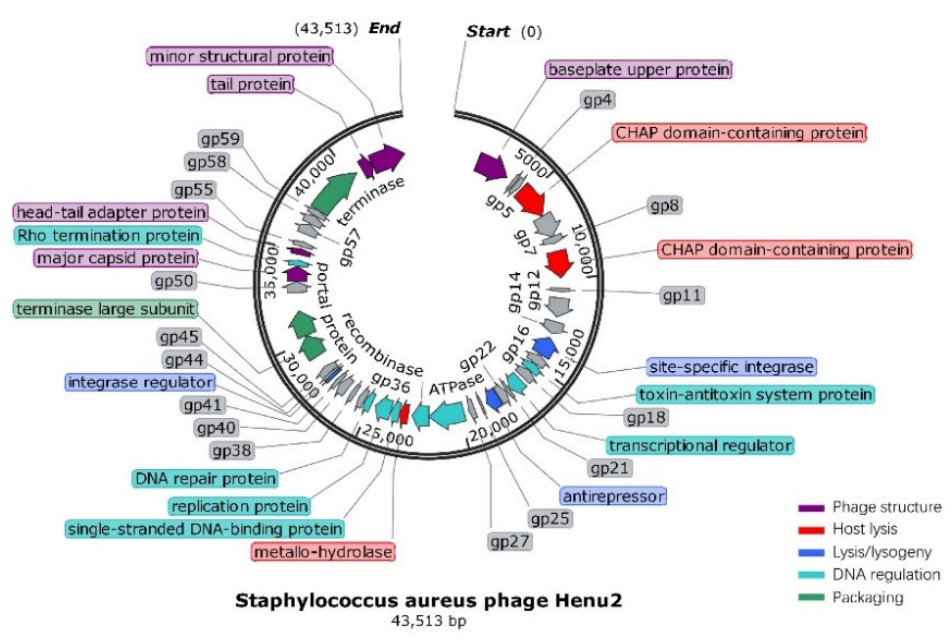

B

Figure 1. (A) Transmission electron micrograph of negatively stained Henu2 phage particles; (B) Genomic map of Staphylococcus aureus phage Henu2: Sixty-three predicted open reading frames (ORFs) are represented by different colored blocks. 


\subsection{General Genome Analysis}

The genomic DNA of Henu2 was extracted as described in the Section 4. The gene map illustrated tightly packed coding regions, with significantly few intergenic spaces between them. The complete genome sequence of Henu2 had a linear double-stranded DNA molecule of $43,513 \mathrm{bp}$ with $35 \% \mathrm{G}+\mathrm{C}$ content. The gene-coding potential of Henu2 is $92.2 \%$ with 1.46 genes per kilobase pair of nucleotide sequence, a number similar to that reported for S. aureus bacteriophage 66 (1.48 genes per kbp) [43]. Additionally, it was found that Henu2 phage belongs to class-II (about $40 \mathrm{kbp}$ ) based on genomic size (Table S1).

\subsection{Biological Characteristics of Henu2 Phage}

To determine the optimal MOI, the phage Henu2 was incubated with $S$. aureus strain N315 with five MOI values of $0.001,0.01,0.1,1$ and 10, respectively. Based on the findings in Table 1, the phage titer reached $6 \times 10^{8} \mathrm{PFU} / \mathrm{mL}$ when $\mathrm{MOI}=0.1$ was the highest titer among the above five MOI values. Therefore, the optimal MOI of phage Henu2 was 0.1. According to the results shown in Figure 2A (Table S4), Henu2 has a latent period of approximately $20 \mathrm{~min}$ and a burst size of approximately 7.8 PFU per infected cell.

Table 1. Optimal multiplicity of infection (MOI) of bacteriophage Henu2.

\begin{tabular}{cccc}
\hline $\begin{array}{c}\text { Phage Titer } \log _{10} \\
\text { (PFU/mL) }\end{array}$ & $\begin{array}{c}\text { Bacterial Titer Log } \mathbf{1 0} \\
\text { (CFU/mL) }\end{array}$ & MOI & Mean \pm SD \\
\hline 7.78 & 6.78 & 10 & $8.26 \pm 0.20$ \\
6.78 & 6.78 & 1 & $6.84 \pm 0.05$ \\
5.78 & 6.78 & 0.1 & $8.77 \pm 0.06$ \\
4.78 & 6.78 & 0.01 & $6.69 \pm 0.07$ \\
3.78 & 6.78 & 0.001 & $5.59 \pm 0.09$ \\
\hline
\end{tabular}

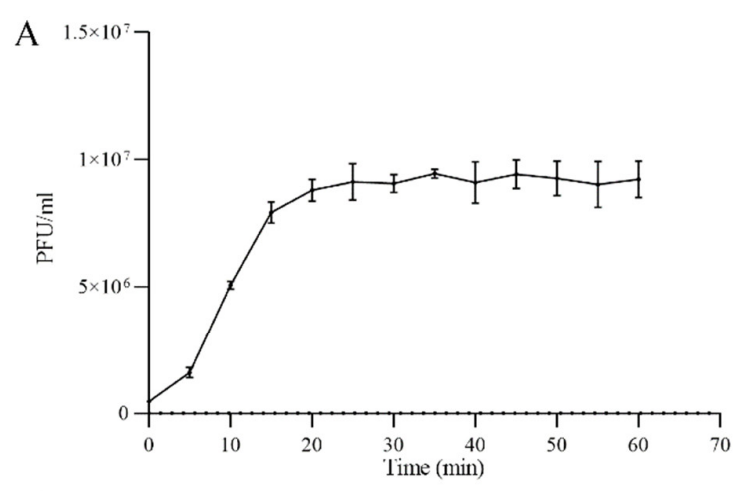

C

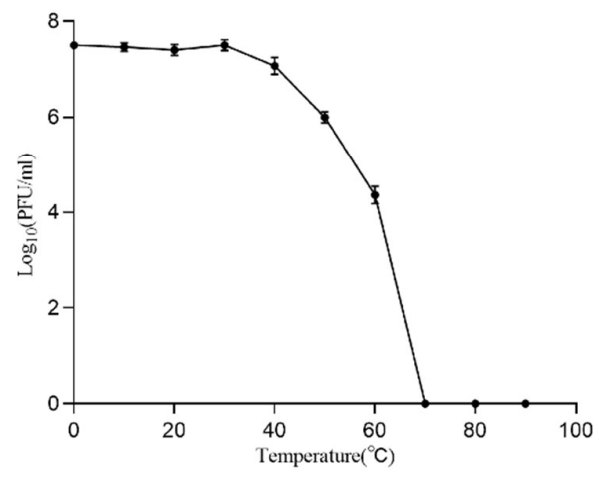

B

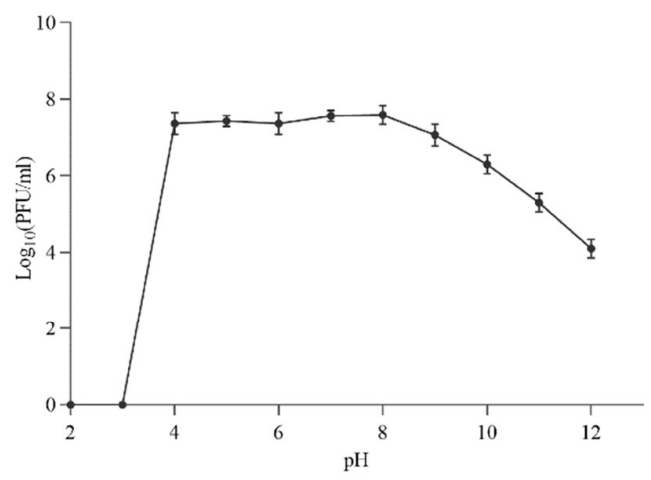

$\mathrm{D}$

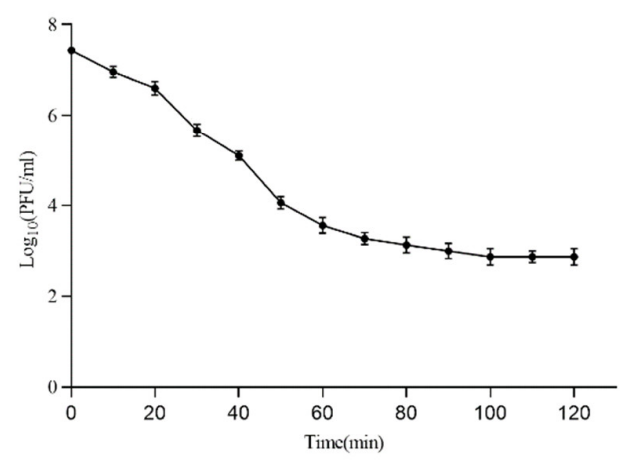

Figure 2. (A) One-step growth experiment; (B) pH stability test; (C) Thermal stability test; (D) and UV sensitivity of phage Henu2. 
Furthermore, Henu2 infectivity towards S. aureus remained unaffected by chloroform, indicating that Henu2 was not a lipid-containing phage. Phage Henu2 retained its infectivity toward S. aureus when incubated at $50^{\circ} \mathrm{C}$ or lower, indicating satisfactory thermal stability. Nevertheless, the titer of Henu2 gradually decreased when incubated at a temperature higher than $50{ }^{\circ} \mathrm{C}$ (Figure 2C, Table S6). Phage Henu2 was stable for $1 \mathrm{~h}$ at $\mathrm{pH}$ values from 4 to 11 . Almost no viable phages were observed at $\mathrm{pH}$ values $2-3$. These results suggest that extreme $\mathrm{pH}$ potentially affect phage Henu2 infectivity (Figure 2B, Table S5). The UV sensitivity test of phage Henu2 showed that the titer of Henu2 had a significant reduction in the first $60 \mathrm{~min}$, then slowly reduced at $40 \mathrm{~min}$ and stabilized at 100 min (Figure 2D, Table S7).

\subsection{Comparative Genome Analysis}

A total of 20 Staphylococcal phages showed similarity with Henu2 based on BLASTn (Table S2). The genome length of all the phages listed in Table S2 was about $40 \mathrm{k}$ bp except phage UPMK_1. The total of phage had a high identity with Henu2 $(\geq 92 \%)$, but low query cover $(\leq 63 \%)$, particularly for phiBU01 and 3-AJ-2017 (19\% and 20\%, respectively). Phylogenetic analysis of Henu2 based on large-subunit of terminase indicated that Henu2 was most similar to the phage 52A and X2. Meanwhile, comparative genome analysis was performed using Artemis Comparison Tool (ACT) among phage Henu2, 52A and X2. As shown in Figure 3B, the genes implicated in the structure and assembly of phages were highly similar in all three genomes.

Interestingly, upon BLASTn analysis of Henu2, several prophage genomes integrated into S. aureus genome were observed in the results of BLASTn analysis. One S. aureus strain (S. aureus isolate 17_LA_343, Accession: LT992471) was predicted to contain five prophages, three genomes of which were intact (Table 2). Furthermore, comparative genome analysis was performed among Henu2 and three intact prophages as shown in Figure 3C-E.

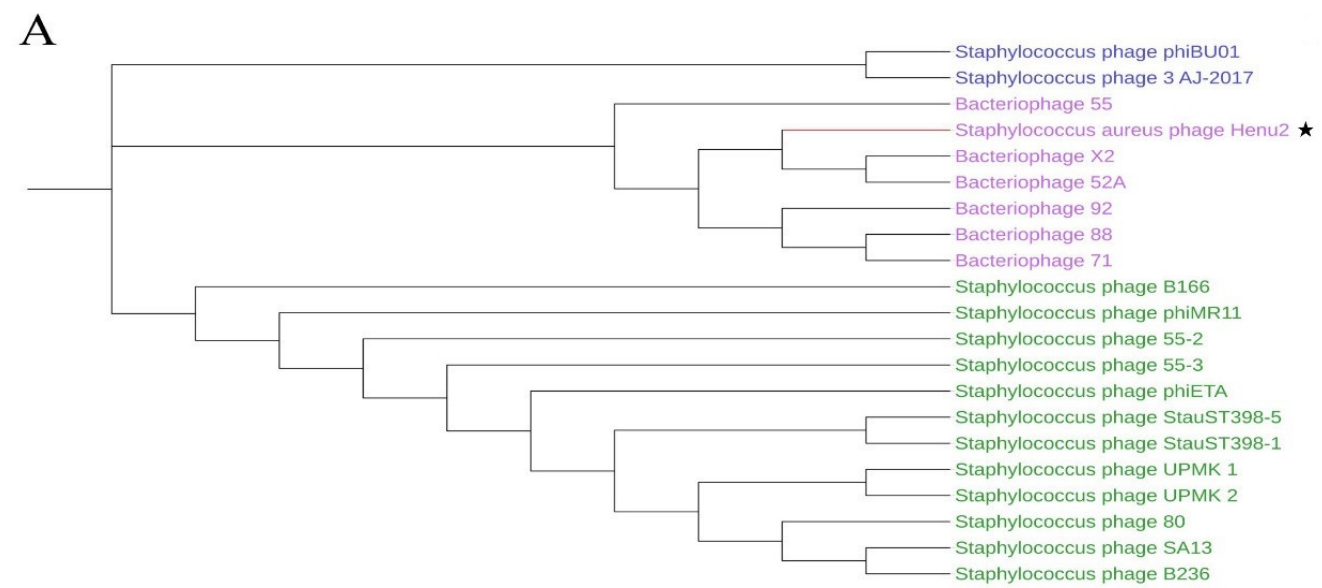

Figure 3. Cont. 
B

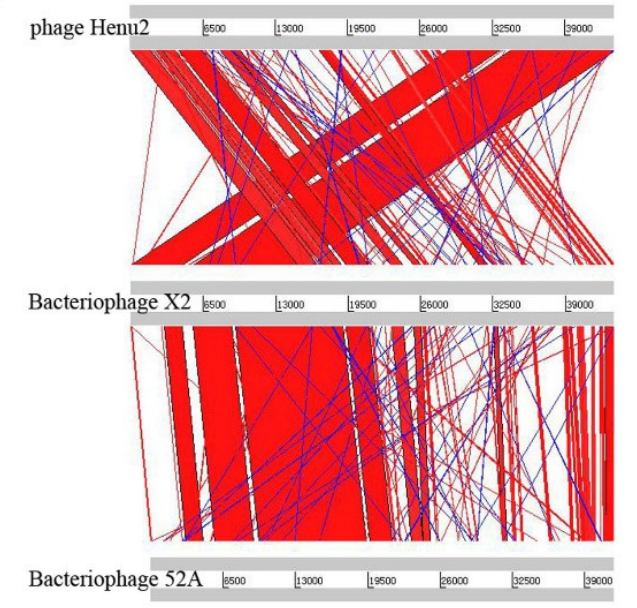

C

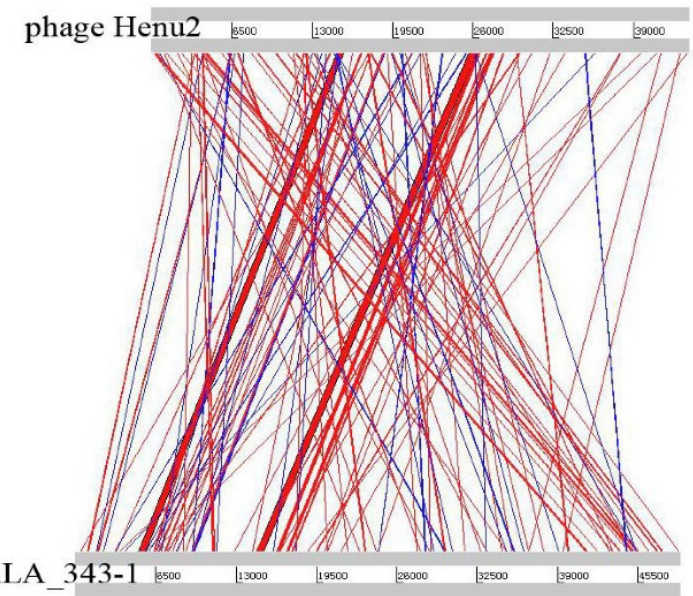

E

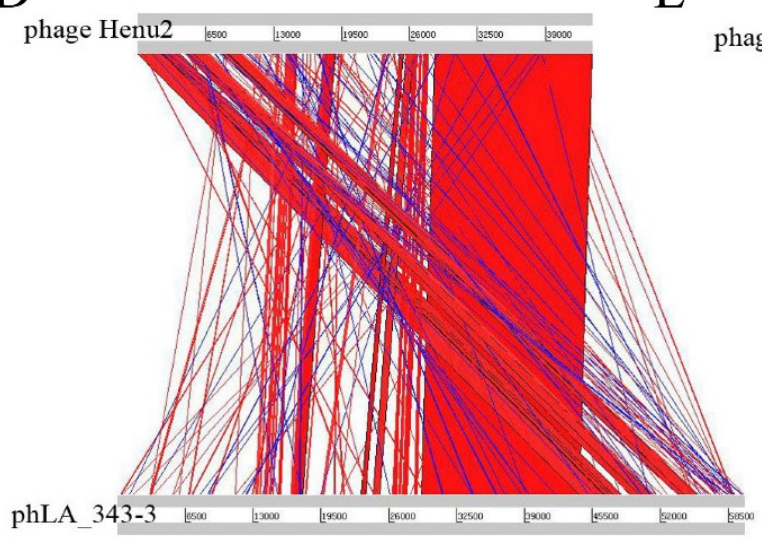

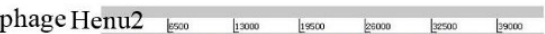

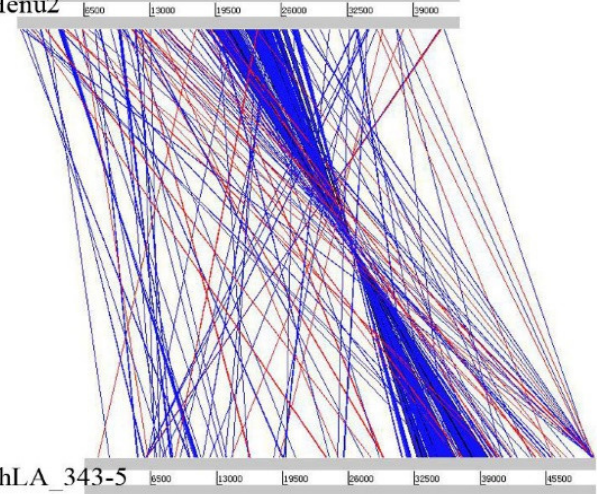

Figure 3. (A) Phylogenetic analysis of various phages that infect Staphylococcus aureus. The tree was drawn by MEGA7 program using the NJ method based on the gene encoding terminase; (B) comparative genome analysis of phage Henu2, bacteriophage 52A and Bacteriophage X2. Comparisons were performed using the BLASTn and ACT (Artemis Comparison Tool) programs; (C-E) comparative genome analysis of phage Henu2, bacteriophage LA_343-1, bacteriophage LA_343-3 and bacteriophage LA_343-5. Red and blue lanes connecting genomes represent syntenic blocks in direct and reverse orientations, respectively.

Table 2. Summary of genomics features of prophage in Staphylococcus aureus isolate 17_LA_343.

\begin{tabular}{cccccc}
\hline $\begin{array}{c}\text { Prophage } \\
\text { Name }\end{array}$ & $\begin{array}{c}\text { Region } \\
\text { Length }\end{array}$ & Completeness & $\begin{array}{c}\text { CDS } \\
\text { Number }\end{array}$ & Region Position & GC Content \\
\hline phLA_343-1 & $48.8 \mathrm{Kbp}$ & Intact & 71 & $389,425-438,317$ & $33.71 \%$ \\
phLA_343-2 & $16.4 \mathrm{Kbp}$ & Incomplete & 17 & $502,332-518,743$ & $31.96 \%$ \\
phLA_343-3 & $60 \mathrm{Kbp}$ & Intact & 75 & $924,419-984,468$ & $35.49 \%$ \\
phLA_343-4 & $22 \mathrm{Kbp}$ & Incomplete & 10 & $2,129,407-2,151,503$ & $28.98 \%$ \\
phLA_343-5 & $50.3 \mathrm{Kbp}$ & Intact & 71 & $2,147,904-2,198,245$ & $32.66 \%$ \\
\hline
\end{tabular}

\subsection{Host Range of Phage Henu2}

The host range of phage Henu2 was analyzed as spot test assay and relative efficiency of plating (REOP) for 41 S. aureus strains and 9 other strains as shown in Table 3 [44]. Henu2 phage demonstrated a wide host range infecting 34 out of 41 S. aureus strains, including MRSA and MSSA strains. Interestingly, that the infectivity of Henu2 did not depend on drugs susceptibility patterns of $S$. aureus strains. A total of nine non-S. aureus strains were resistant to Henu2 phage infection. These results indicate that Henu2 specifically targets S. aureus [45]. 
Table 3. Host range analysis of phage Henu2.

\begin{tabular}{|c|c|c|c|c|}
\hline No. & Strains & Source & Spot Assay & REOP \\
\hline 1 & S. aureus AB91118 (MSSA) & ССТСС & + & 1 \\
\hline 2 & S. aureus KFS1001 (MSSA) & Human & - & - \\
\hline 3 & S. aureus KFS1002 (MSSA) & Human & + & 0.86 \\
\hline 4 & S. aureus KFS1003 (MSSA) & Human & + & 0.08 \\
\hline 5 & S. aureus KFS1006 (MSSA) & Human & + & 0.13 \\
\hline 6 & S. aureus KFS1007 (MSSA) & Human & - & 0 \\
\hline 7 & S. aureus KFS1008 (MSSA) & Human & - & 0 \\
\hline 8 & S. aureus KFS1009 (MSSA) & Human & + & 0.34 \\
\hline 9 & S. aureus KFS1010 (MSSA) & Human & + & 0.26 \\
\hline 10 & S. aureus KFS1013 (MSSA) & Human & + & 0.24 \\
\hline 11 & S. aureus KFS1014 (MSSA) & Human & + & 0.32 \\
\hline 12 & S. aureus KFS1015 (MSSA) & Human & + & 0.12 \\
\hline 13 & S. aureus KFS1016 (MSSA) & Human & + & 0.66 \\
\hline 14 & S. aureus KFS1017 (MSSA) & Human & + & 0.21 \\
\hline 15 & S. aureus KFS1018 (MSSA) & Human & + & 1.03 \\
\hline 16 & S. aureus KFS1027 (MSSA) & Human & + & 0.42 \\
\hline 17 & S. aureus KFS1028 (MSSA) & Human & + & 0.05 \\
\hline 18 & S. aureus KFS1029 (MSSA) & Human & + & 0.13 \\
\hline 19 & S. aureus KFS1030 (MSSA) & Milk & + & 0.42 \\
\hline 20 & S. aureus KFS1031 (MSSA) & Milk & + & 0.04 \\
\hline 21 & S. aureus KFS1032 (MSSA) & Milk & + & 0.37 \\
\hline 22 & S. aureus KFS1033 (MSSA) & Milk & + & 0.02 \\
\hline 23 & S. aureus KFS1034 (MSSA) & Livestock & + & 0.75 \\
\hline 24 & S. aureus KFS1035 (MSSA) & Livestock & + & 0.17 \\
\hline 25 & S. aureus KFS1036 (MSSA) & Livestock & + & 0.09 \\
\hline 26 & S. aureus KFS1037 (MSSA) & Livestock & + & 0.36 \\
\hline 27 & S. aureus KFS1038 (MSSA) & Livestock & + & 0.93 \\
\hline 28 & S. aureus KFS1039 (MSSA) & Livestock & + & 0.50 \\
\hline 29 & S. aureus N315 (MRSA) & Human & + & 0.50 \\
\hline 30 & S. aureus AM001 (MRSA) & Human & + & 0.10 \\
\hline 31 & S. aureus AM002 (MRSA) & Human & + & 0.33 \\
\hline 32 & S. aureus AM005 (MRSA) & Human & - & 0 \\
\hline 33 & S. aureus AM006 (MRSA) & Human & - & 0 \\
\hline 34 & S. aureus AM007 (MRSA) & Human & + & 0.25 \\
\hline 35 & S. aureus AM008 (MRSA) & Human & - & 0 \\
\hline 36 & S. aureus AM010 (MRSA) & Human & + & 0.38 \\
\hline 37 & S. aureus AM018(MRSA) & Human & + & 0.03 \\
\hline 38 & S. aureus AM022 (MRSA) & Human & + & 0.09 \\
\hline 39 & S. aureus AM023 (MRSA) & Human & + & 0.21 \\
\hline 40 & S. aureus AM024 (MRSA) & Human & - & 0 \\
\hline 41 & S. aureus AM025 (MRSA) & Human & - & 0 \\
\hline 42 & L. monocytogenes 19115 & ATCC & - & 0 \\
\hline 44 & B. thuringiensis 1765 & Lab storage & - & 0 \\
\hline 45 & B. cereus IS195 & Lab storage & - & 0 \\
\hline 46 & E. faecium 35667 & ATCC & - & 0 \\
\hline 47 & E. coli BL21(DE3) & Lab storage & - & 0 \\
\hline 48 & S. dysgalactiae 35666 & ATCC & - & 0 \\
\hline 49 & S. albus 8799 & ATCC & - & 0 \\
\hline 50 & B. cereus $33018 \mathrm{R}$ & ATCC & - & 0 \\
\hline 51 & S. pyogenes 12344 & ATCC & - & 0 \\
\hline
\end{tabular}

MSSA, methicillin-susceptible S. aureus; MRSA, methicillin-resistant S. aureus; CCTCC: China Center for Type Culture Collection; ATCC: American Type Culture Collection; REOP: relative efficiency of plating. REOP was determined as ratio of plaque forming unit (PFU) on S. aureus $\mathrm{AB} 91118$ versus PFU on the control strains; + , clear plaques; - , no plaque.

\subsection{Effect of Sub-Lethal Antibiotics on Adsorption and Burst Size of Phage Henu2}

PAS is a phenomenon where the sub-lethal concentration of a few antibiotics significantly stimulates the generation of progeny phages in host bacterial cells [21]. The MIC 
values of the antibiotics used in this study are shown in Table S3. The growth characteristics of phage Henu2, including phage absorption rate and burst size, were used to detect whether phage Henu2 had a synergistic effect with sub-lethal concentrations of antibiotics. The results shown in Figure 4A indicate the total time required for phage adsorption in the presence of five different antibiotics and hydrogen peroxide. The findings revealed $20 \mathrm{~min}$ as the average adsorption time of phage Henu2 on the surface of S. aureus. Clarithromycin and linezolid bound to the $50 \mathrm{~S}$ ribosome and inhibited bacterial protein synthesis causing a reduction of the total adsorption time of Henu2 from $20 \mathrm{~min}$ to $12 \mathrm{~min}$ and $14 \mathrm{~min}$, respectively. Similarly, in the presence of Cefotaxime, an inhibitor of bacterial cell wall synthesis, the adsorption time significantly shortened to $16 \mathrm{~min}$. In the case of tetracycline and ciprofloxacin, a significant decrease in the time required for $80 \%$ adsorption (12 $\mathrm{min}$ and $16 \mathrm{~min}$, respectively) was observed. Interestingly, Henu2 had an adsorption time of 15 min with hydrogen peroxide.

A

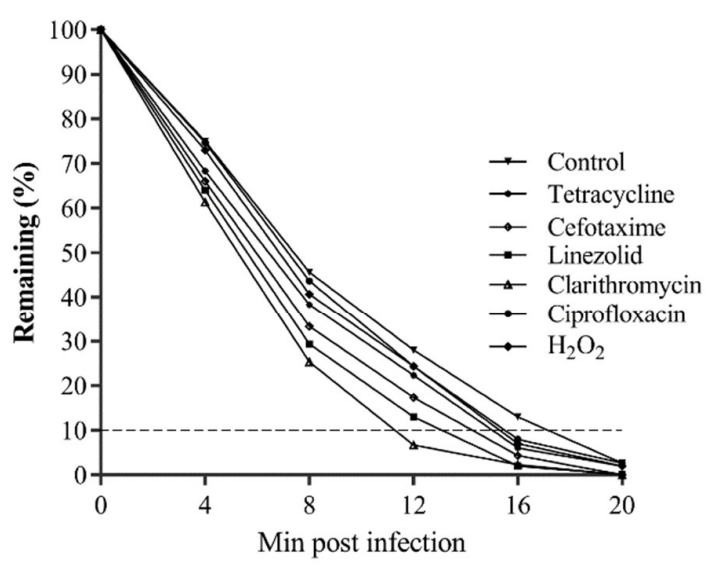

B

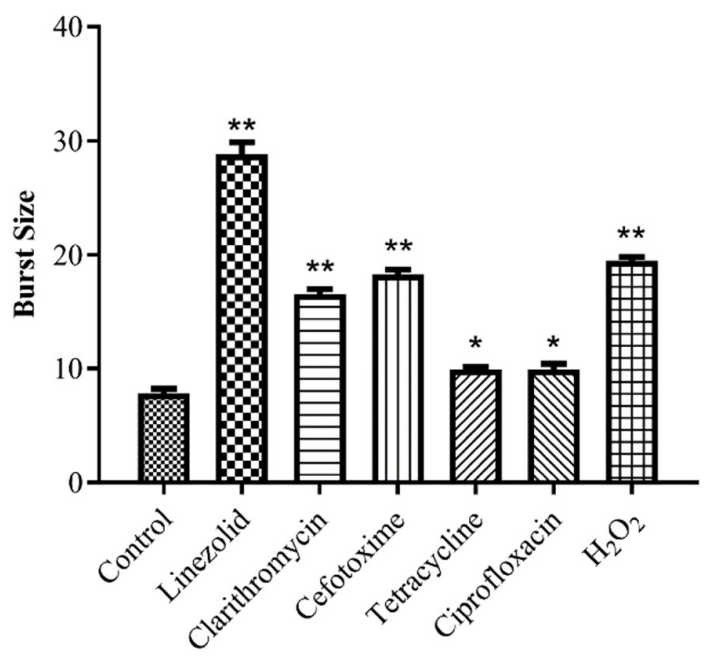

Figure 4. (A) Adsorption of phage Henu2 to S. aureus (MOI = 0.1) in the presence of sub-lethal concentrations of various antibiotics $(p<0.01), 90 \%$ phage adsorbed to host bacteria is used as cutoff; (B) Burst sizes measured in the presence of antibiotics inducing PAS $(*, p<0.05 ; * *, p<0.01)$.

At 20 min post-infection in the absence of any antibiotics, the decrease of the numbers of phage Henu2 was stopped in culture medium, indicating the occurrence of bacterial burst (Figure 4A, Table S8). The average burst size was 7.8 phages released per host cell, with a phage absorption period of $20 \mathrm{~min}$. In contrast, clarithromycin and linezolid significantly increased the burst size, to an average value of 16.6 and 28.8 phage/cell $(p<$ $0.01)$. Similarly, an increase in the burst size was from 7.8 to 18.3 phage/cell. $(p<0.05)$ was observed with Cefotaxime as well. Tetracycline and ciprofloxacin were nearly comparable with each other, significantly increasing the burst size by 9.9 phage/cell. Nonetheless, in the presence of a sub-lethal dose of hydrogen peroxide, the increase in burst size was 2.5-fold (19.5 phage/cell) (Figure 4B, Table S9).

\subsection{Time-Kill Analyses for Assessing the PAS Efficacy}

The antibacterial effect of phages, antibiotic and phage/antibiotic combination was assessed against $S$. aureus at $37^{\circ} \mathrm{C}$ as illustrated in Figure 5 (Table S10). The cell number of $S$. aureus was increased by $0.6-1.8 \operatorname{logs}$ over $12 \mathrm{~h}$ in the presence of sub-inhibitory concentrations of five different antibiotics and hydrogen peroxide alone. After treatment with phage Henu2 alone, the number of $S$. aureus continuously decreased up to $10 \mathrm{~h}$ then steadily increased. In contrast, the combination treatment of phage Henu2 and antibiotics, including clarithromycin, linezolid, cefotaxime, tetracycline, ciprofloxacin and hydrogen peroxide, significantly inhibited the growth of S. aureus up to the early $12 \mathrm{~h}$ of incubation, 
causing 2.6-4.4 logs reductions. These results verify that phage Henu2 combined with the sub-inhibitory concentrations antibiotics effectively decreased the cell concentrations of S. aureus.

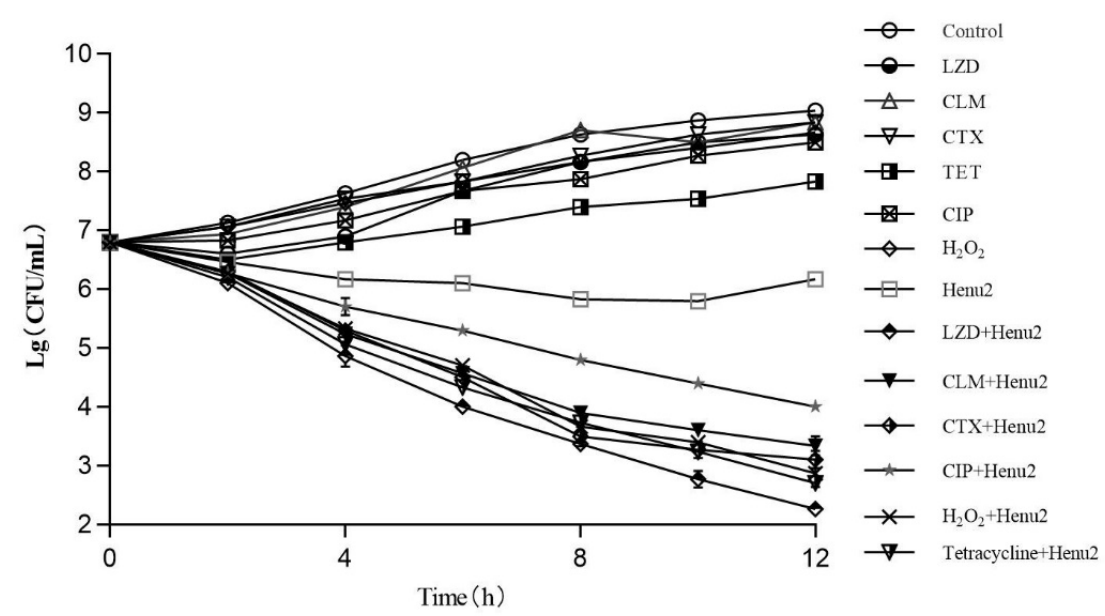

Figure 5. Killing effect of phage Henu2 on S. aureus N315 logarithmic phase cells in the presence of linezolid (LZD) *, clarithromycin (CLM) ${ }^{*}$, cefotaxime (CTX) ${ }^{*}$, ciprofloxacin (CIP) ${ }^{*}$, tetracycline (TET) * and hydrogen peroxide *; Cells were treated with $2.25 \mu \mathrm{g} / \mathrm{mL}$ linezolid, $4.1 \mu \mathrm{g} / \mathrm{mL}$ clarithromycin, $16 \mu \mathrm{g} / \mathrm{mL}$ Cefotaxime, $1.25 \mu \mathrm{g} / \mathrm{mL}$ ciprofloxacin, $7 \mu \mathrm{g} / \mathrm{mL}$ tetracycline or $0.25 \%$ hydrogen peroxide. Phage Henu2 was added at a MOI of 0.1 Values given are averages standard deviations from three replicates $\left({ }^{*}, p<0.01\right)$.

\section{Discussion}

S. aureus infecting phage Henu2 was isolated, intensely characterized with phenotypes and genomes, and analyzed for antimicrobial activity. Based on genome sequence similarity, Henu2 was classified as a member of the genus Phietavirus in the family of Siphoviridae [46]. High genetic similarity between Henu2 and prophage suggested that Henu2 might be originating from the prophage embedded in the genome of S. aureus isolate 17_LA_343. The prophage genome is often integrated into the bacterial chromosome as a lysogenic cycle of temperate phage [47,48]. The repressor and anti-repressor proteins were responsible for the switch of the lytic and lysogenic cycle of prophage. In the Henu2 genome, one antirepressor protein was detected, but not the repressor. Hatful et al. showed that most of the two proteins encoding gene (NTRK3) in the lytic phage were mutated in the evolutionary process [49]. Based on this, it is tempting to speculate that Henu2 might be transformed into a lytic phage by losing the inhibitor protein during the evolution process.

This paper used S. aureus N315 as a host to evaluate the biological characteristics and bactericidal activity of phage Henu2. Nonetheless, using PHASTER online tool, two prophages were presented in the genome of $S$. aureus N315, one which was an intact prophage with $47 \mathrm{~kb}$ length and the other was questionable with $19.9 \mathrm{~kb}$ length according to the criteria for scoring prophage regions (as intact, questionable, or incomplete) [50,51]. However, both prophages genomes contained enterotoxin coding genes. As previously mentioned, many factors influence the induction of prophages including antibiotics, UV, temperature or $\mathrm{H}_{2} \mathrm{O}_{2}$ that are well documented [52,53]. Thus, further studies are necessary to establish either or not antibacterial and $\mathrm{H}_{2} \mathrm{O}_{2}$ induce the production of endotoxin in host bacteria.

A comprehensive mechanism of plaque formation remains unknown to scholars. Despite many factors influencing this process, only a few factors have been extensively studied. Therefore, the problems on plaque morphology and size are common in laboratory practice. Based on previous reports, two widely recognized factors were considered responsible for the enlarged plaques, including filamentation of bacteria and the delayed lysis of bacteria. Filamentation of cells produced by antibiotics or other external factors increased its surface area, thereby promoting more phage adsorption and the generation 
of progeny phage. The phenomenon of delayed lysis of bacteria, caused by the effect of sublethal concentration antibiotics, influenced the lysis period of bacteria and increased the number of phage copies before the lysis of bacteria [36]. Using the double-layer agar plate (DLAP) method, we found that the plaque formed by phage Henu2 had no difference with the antibiotic treatment group. ŁOS' et al. demonstrated that the size and morphology of plaques were influenced by several factors, including the types of carbon sources in the medium, the selected strains as host bacteria, the number of host bacteria, the types of antibiotics and the thickness of the upper agar, etc. [14,54]. Meanwhile, the burst size and latent period of phages were significantly affected by these factors. As such, further research should be conducted to investigate the effect of different detection methods on phage production.

Moreover, the complex physiological environment showed a significant effect on the activity of phages combined with antibiotics. The undesired side-effects and beneficial effects of phage infection in vivo include. First, based on the latest reports, the observed synergism effect of phages with antibiotics might be decreased when the culture conditions were changed into urine or blood similar to the physiological environment of the human body $[55,56]$. Furthermore, the host bacteria degraded by phages produced many proteins, lipids, endotoxin and cell fragments, released into the human internal environment often causing inflammation. Finally, a few antibiotics might stimulate the expression of virulence genes, indicating that the type of antibiotics should be selected to prevent over-generation of virulence products [57]. However, phages also demonstrated profound effects on the outcome of bacterial infections by modulating the immune response. Reports indicate that immune cells, including macrophages and neutrophils, also have a synergistic effect with phages in vivo, known as immune-phage synergy [58]. Although the specific mechanism needs to be addressed, studies have shown that phages improve the phagocytic capacity of macrophages [59,60], and preferentially enhance the elimination of phage-resistant bacteria by neutrophils [61-64].

In conclusion, despite phage potentially having synergistic effects with antibiotics in vitro and in vivo [61,65], several issues should be first resolved for its clinical application and a greater focus on the decrease of the possible harm to humans warrants investigation in further research.

\section{Materials and Methods}

\subsection{Isolation and Purification of S. aureus Phage}

S. aureus N315, a drug-resistance strain, was stored in our lab and used as a host. Bacteriophage Henu2 was isolated from sewage water obtained from Campus Lake in Henan University using the double-layer agar method as previously described by Pajunen et al. [66]. Briefly, $10 \mathrm{~mL}$ sewage samples were mixed with $10 \mathrm{~mL}$ Luria-Bertani (LB) medium and $1 \mathrm{~mL}$ S. aureus N315, then co-incubated in conical flasks at $30^{\circ} \mathrm{C}$ with shaking in $180 \mathrm{rpm}$ for $48 \mathrm{~h}$. The culture was filtered using a $0.22 \mu \mathrm{m}$ membrane filter and the filtration product was serially diluted to detect phage activity using a double-layer agar plate. A single plaque was picked up from the double-layer agar plate using a sterile inoculation loop then serially purified 6 times. The TE buffer $(13.6 \mathrm{mM} \mathrm{NaCl}, 2 \mathrm{mM}$ Tris, 2 $\mathrm{mM} \mathrm{MgCl}_{2}$ and $0.01 \%$ gelatin, $\mathrm{pH}$ 7.5) was used to prepare the stock cultures of Henu2.

\subsection{Electron Microscopy}

The morphology of Henu2 was identified via transmission electron microscopy. Phage particles were purified by centrifugation at $4{ }^{\circ} \mathrm{C}$ with a speed of $25,000 \mathrm{~g}$ for $1 \mathrm{~h}$ using a Beckman J2-21 centrifuge with a JA-18.1 fixed rotor. The purified phage was adsorbed to carbon-coated copper grids, fixed with glutaraldehyde $(2.5 \% v / v)$ and negatively stained with $3 \%$ uranyl acetate. After drying, grids were examined under a transmission electron microscope JEM-1400 at $200 \mathrm{kV}$. 


\subsection{Phage DNA Isolation}

Extraction of phage DNA was performed using chloroform-standard phenol extraction method as previously described [67] with a few modifications. To remove free DNA and RNA, DNase I and RNase with a final concentration of $5 \mu \mathrm{g} / \mathrm{mL}$ and $1 \mu \mathrm{g} / \mathrm{mL}$, respectively, were incubated with the sample at $37^{\circ} \mathrm{C}$ for $1 \mathrm{~h}$. Then, Tris-Saturated Phenol was used to extract nucleic acid from the solution and this step was repeated twice. The sample was precipitated with the $1 / 10$ sodium acetate $(v / v)$ and $1 / 1$ absolute ethanol $(v / v)$, respectively. Then, the above solution was stored at $-20{ }^{\circ} \mathrm{C}$ overnight then centrifuged to remove the supernatant. The precipitate was washed twice with absolute and $70 \%$ ethanol. The quantity and purity of DNA extracted was spectrophotometrically investigated using a Nanodrop.

\subsection{Genome Sequencing and Termini Identification}

The complete genome was sequenced using 454 technology with the GS Junior 454 system platform (Roche Applied Science, Indianapolis, IN, USA), yielding 6.5-fold coverage of the phage genome [68]. Prediction of open reading frames (ORFs) was performed using softberry (http:/ / linux1.softberry.com/ (accessed on 8 February 2021)) and Glimmer. A whole-genome sequence assembly was performed using Geneious software version 6 while Phage termini were identified using the method described by Zhang et al. [69].

\subsection{The Multiplicity of Infection (MOI) of Phage Henu2}

To determine the optimal MOI, the logarithmic phase S. aureus and a serial dilution of Henu2 were co-incubated in $1.5 \mathrm{~mL}$ polypropylene tubes. The ratio of bacteriophage and S. aureus was adjusted to 10, 1, 0.1, 0.01 and 0.001 respectively. Then, the mixture was cultured in a shaking incubator at $30^{\circ} \mathrm{C}$, for $4 \mathrm{~h}$. Subsequently, the mixture was centrifuged at 10,000 rpm for $1 \mathrm{~min}$ and filtered to remove the host bacteria. Then the bacteriophage titer was determined using the double-layer agar method. The mixture with a ratio of Henu2 to $S$. aureus with the highest phage titer value was considered the optimal multiplicity of infection (OMOI). A total of 3 replicates were performed.

\subsection{One-Step Growth Curve of Phage Henu2}

S. aureus was infected with phage Henu2 at an MOI of 0.1 then incubated at $30^{\circ} \mathrm{C}$ for $10 \mathrm{~min}$. The mixture was then centrifuged at $10,000 \mathrm{rpm}$ for $1 \mathrm{~min}$ to remove unabsorbed phage particles. The cell pellet was quickly re-suspended in $1 \mathrm{~mL}$ of fresh Luria-Bertani (LB) medium. Subsequently, the suspension was added to $5 \mathrm{~mL}$ of LB broth and incubated in a shaking incubator at $30^{\circ} \mathrm{C}$. Meanwhile, the sample was collected at intervals of every $5 \mathrm{~min}$ for one hour. The phage titer was determined by the double-layer agar plate method. A total of 3 replicates were performed.

\subsection{Thermal, $\mathrm{pH}$, and Chloroform Stability Tests}

The phage suspensions in normal saline with a titer of $5 \times 10^{7}$ were incubated at various temperatures $\left(0\right.$ to $\left.80^{\circ} \mathrm{C}\right)$ and aliquot $(100 \mu \mathrm{L})$ were collected after $1 \mathrm{~h}$, respectively. Then, the double-layer agar and spot test were used to evaluate the thermal stability of Henu2. To evaluate the $\mathrm{pH}$ stability of the Henu2 phage, the $\mathrm{pH}$ of the phage buffer was adjusted in wide range from 2 to 12 . After incubating at $30^{\circ} \mathrm{C}$ for $1 \mathrm{~h}$, the amount of phage Henu2 was diluted and two-layer agar method was used to count the phage titer. To test the effect of chloroform, $10 \mu \mathrm{L}$ chloroform was added to $1 \mathrm{ml}$ of Henu2 suspension with a titer of $1 \times 10^{6}$. The solution was gently mixed and incubated for $1 \mathrm{~h}$ at room temperature. Then, the phage titer was determined by the double agar-layer agar method. Phage Henu2 was exposed to UV at $50 \mathrm{~J} / \mathrm{m}^{2}$. The titer was determined every $10 \mathrm{~min}$ for $2 \mathrm{~h}$ using the double agar-layer agar method. A total of 3 replicates were performed. 


\subsection{The MIC of the Host Bacterial}

To establish the minimum inhibitory concentrations (MIC) of antibiotics, $900 \mu \mathrm{L}$ logarithmic phase host bacteria and $100 \mu \mathrm{L}$ antibiotics with different concentrations (clarithromycin, linezolid, cefotaxime, tetracycline and ciprofloxacin) were mixed into a $1.5 \mathrm{~mL}$ polypropylene tubes, then the $100 \mu \mathrm{L}$ mixture was removed into a 96-wells plant and cultured at $30^{\circ} \mathrm{C}$ for $24 \mathrm{~h}$. The minimum concentration of antibiotics inhibiting the growth of $S$. aureus was considered MIC value. A total of 3 replicates were performed.

\subsection{Bioinformatic Analysis}

BlastP and BlastN in NCBI (https:/ / blast.ncbi.nlm.nih.gov/Blast.cgi (accessed on 8 February 2021)) were used to compare the known Henu2 protein sequence and nucleic acid sequence with protein library and nucleic acid library, respectively. The phylogenetic tree was constructed by MEGA7 software and iTOL (https://itol.embl.de (accessed on 8 February 2021)) [70]. Phage with the greatest similarity to Henu2 was identified by phylogenetic tree, while complete genome sequence alignment, was conducted using a double ACT (http:/ / www.hpa-bioinfotools.org.uk/pise/double_actv2.html (accessed on 8 February 2021)) online program. The functional proteins were indicated by different colors, while the hypothetical proteins were marked with yellow. Based on the GenBank information, a web-based tool called SnapGene was used for making a map of Henu2 genomes [71,72].

\subsection{Host Range Analysis}

Phage host range was established using a spot test and efficiency-of-plating (EOP) method combined with double-layer agar plate method following a previously described protocol $[73,74]$. All the tested strains listed in Table 3 were cultured for $16 \mathrm{~h}$ at $30^{\circ} \mathrm{C}$. Then, $150 \mu \mathrm{L}$ of the bacterial culture of each strain was added to $3 \mathrm{~mL}$ of the $0.8 \%$ soft agar and overlaid on the LB or Brain Heart Infusion (BHI) agar plate. Phage titer of Henu2 was adjusted to $10^{6} \mathrm{PFU}$ with phage buffer, and $5 \mu \mathrm{L}$ of phage suspension was spotted onto the surface of double-layer agar plate then incubated at $30^{\circ} \mathrm{C}$ for $36 \mathrm{~h}$ and the plaque formation was examined at every $8 \mathrm{~h}$. For the efficiency-of-plating (EOP) method, $10 \mu \mathrm{L}$ phage was mixed with $150 \mu \mathrm{L}$ each strain bacterial culture and incubated at $30^{\circ} \mathrm{C}$ for $5 \mathrm{~min}$. Then, the mixture added to $3 \mathrm{ml}$ efficiency of plating (EOP) was calculated by dividing the phage titer on the test strain by the phage titer on the reference strain. A total of 3 replicates were performed.

Supplementary Materials: The following are available online at https:/ /www.mdpi.com/2079-638 2/10/2/174/s1, Table S1: Predicted molecular function for gene products of phage Henu2, Table S2: Summary of similar genomic sequence with phage Henu2, Table S3: List of MIC values of antibiotics, Table S4: One-step growth experiment (Mean \pm SD), Table S5: $\mathrm{pH}$ stability test (Mean \pm SD), Table S6: Thermal stability test (Mean \pm SD), Table S7: UV sensitivity of phage Henu2 (Mean \pm SD), Table S8: Adsorption of phage Henu2 to $S$. aureus (MOI = 0.1, Mean \pm SD), Table S9: Burst sizes measured in the presence of antibiotics inducing PAS (Mean \pm SD), Table S10: Killing effect of phage Henu2 on S. aureus N315 logarithmic phase cells (Mean \pm SD).

Author Contributions: Conceptualization, T.T. and Y.L.; methodology, G.W. and Y.H.; software, X.L.; validation, A.E.A.; resources, T.T.; data curation, T.T.; writing—original draft preparation, Y.H.; writing - review and editing, G.W., J.W. and T.H.; supervision, Y.L.; funding acquisition, T.T. and Y.L. All authors have read and agreed to the published version of the manuscript.

Funding: This research was funded by the Key R\&D and Promotion Projects of Henan Province, grant number 192102310156; National undergraduate innovation and entrepreneurship training program, grant number 202010475006.

Data Availability Statement: Data is contained within the article or supplementary material. Complete genome of Staphylococcus phage Henu2 is available in https:/ / www.ncbi.nlm.nih.gov/nuccore/ under the GenBank accession number MK211557.1. 
Conflicts of Interest: The authors declare no conflict of interest.

\section{References}

1. Van Belkum, A.; Verkaik, N.J.; De Vogel, C.P.; Boelens, H.A.; Verveer, J.; Nouwen, J.L.; Verbrugh, H.A.; Wertheim, H.F. Reclassification of Staphylococcus Aureus Nasal Carriage Types. J. Infect. Dis. 2009, 199, 1820-1826. [CrossRef]

2. Tong, S.Y.; Davis, J.S.; Eichenberger, E.; Holland, T.L.; Fowler, V.G., Jr. Staphylococcus Aureus Infections: Epidemiology, Pathophysiology, Clinical Manifestations, and Management. Clin. Microbiol. Rev. 2015, 28, 603-661. [CrossRef] [PubMed]

3. Peacock, S.J.; Paterson, G.K. Mechanisms Of Methicillin Resistance In Staphylococcus Aureus. Annu. Rev. Biochem. 2015, 84, 577-601. [CrossRef]

4. Chai, L.Q.; Meng, J.H.; Gao, J.; Xu, Y.H.; Wang, X.W. Identification of a Crustacean B-1,3-Glucanase Related Protein as a Pattern Recognition Protein in Antibacterial Response. Fish Shellfish Immunol. 2018, 80, 155-164. [CrossRef]

5. Goudarzi, M.; Goudarzi, H.; Am, S.F.; Udo, E.E.; Fazeli, M.; Asadzadeh, M.; Seyedjavadi, S.S. Molecular Characterization of Methicillin Resistant Staphylococcus Aureus Strains Isolated from Intensive Care Units in Iran: St22-Sccmec Iv/T790 Emerges As The Major Clone. PLoS ONE 2016, 11, e0155529. [CrossRef] [PubMed]

6. Gerlach, D.; Guo, Y.; Castro, C.D.; Kim, S.H.; Peschel, A. Methicillin-Resistant Staphylococcus Aureus Alters Cell Wall Glycosylation to Evade Immunity. Nature 2018, 563, 705-709. [CrossRef]

7. Steinig, E.J.; Duchene, S.; Robinson, D.A.; Monecke, S.; Yokoyama, M.; Laabei, M.; Slickers, P.; Andersson, P.; Williamson, D.; Kearns, A. Evolution and Global Transmission of a Multidrug-Resistant, Community-Associated Methicillin-Resistant Staphylococcus Aureus Lineage from the Indian Subcontinent. mBio 2019, 10, e01105-e01119. [CrossRef]

8. Marcinkiewicz, J.; Strus, M.; Pasich, E. Antibiotic Resistance: A “Dark Side” of Biofilm-Associated Chronic Infections. Pol. Arch. Med. Wewn. 2013, 123, 309-313. [CrossRef]

9. Gutiérrez, D.; Fernández, L.; Rodríguez, A.; García, P.; Gilmore, M.S. Are Phage Lytic Proteins the Secret Weapon to Kill Staphylococcus Aureus? mBio 2018, 9, e01923-17.

10. Topka, G.; Bloch, S.; Nejman-Faleńczyk, B.; Gąsior, T.; Jurczak-Kurek, A.; Necel, A.; Dydecka, A.; Richert, M.; Węgrzyn, G.; Węgrzyn, A. Characterization of Bacteriophage Vb-Ecos-95, Isolated from Urban Sewage and Revealing Extremely Rapid Lytic Development. Front. Microbiol. 2018, 9, 3326. [CrossRef]

11. Necel, A.; Bloch, S.; Nejman-Faleńczyk, B.; Grabski, M.; Topka, G.; Dydecka, A.; Kosznik-Kwaśnicka, K.; Grabowski, Ł.; JurczakKurek, A.; Wołkowicz, T.; et al. Characterization of a Bacteriophage, Vb_Eco4m-7, That Effectively Infects Many Escherichia Coli O157 Strains. Sci. Rep. 2020, 10, 3743. [CrossRef]

12. Wommack, K.E.; Colwell, R.R. Virioplankton: Viruses in Aquatic Ecosystems. Microbiol. Mol. Biol. Rev. 2000, 64, 69-114. [CrossRef]

13. Chauhan, A.; Lebeaux, D.; Ghigo, J.M.; Beloin, C. Full and Broad-Spectrum In Vivo Eradication of Catheter-Associated Biofilms Using Gentamicin-Edta Antibiotic Lock Therapy. Antimicrob. Agents Chemother. 2012, 56, 6310-6318. [CrossRef]

14. Comeau, A.M.; Tétart, F.; Trojet, S.N.; Prère, M.F.; Krisch, H.M. Phage-Antibiotic Synergy (Pas): Beta-Lactam and Quinolone Antibiotics Stimulate Virulent Phage Growth. PLoS ONE 2007, 2, e799. [CrossRef]

15. Morrisette, T.; Lev, K.L.; Kebriaei, R.; Abdul-Mutakabbir, J.C.; Stamper, K.C.; Morales, S.; Lehman, S.M.; Canfield, G.S.; Duerkop, B.A.; Arias, C.A.; et al. Bacteriophage-Antibiotic Combinations for Enterococcus Faecium with Varying Bacteriophage and Daptomycin Susceptibilities. Antimicrob. Agents Chemother. 2020, 64, e00993-20. [CrossRef]

16. Gurney, J.; Brown, S.P.; Kaltz, O.; Hochberg, M.E. Steering Phages to Combat Bacterial Pathogens. Trends Microbiol. 2020, 28, 85-94. [CrossRef]

17. Altamirano, F.L.G.; Barr, J.J. Phage Therapy in the Postantibiotic Era. Clin. Microbiol. Rev. 2019, 32, e00066-18. [CrossRef]

18. Torres-Barcelo, C.; Hochberg, M.E. Evolutionary Rationale for Phages as Complements of Antibiotics. Trends Microbiol. 2016, 24, 249-256. [CrossRef]

19. Raj, J.R.M.; Karunasagar, I. Phages Amid Antimicrobial Resistance. Crit. Rev. Microbiol. 2019, 45, 701-711. [CrossRef]

20. Abedon, S.T. Phage-Antibiotic Combination Treatments: Antagonistic Impacts of Antibiotics on the Pharmacodynamics of Phage Therapy? Antibiotics 2019, 8, 182. [CrossRef]

21. Tagliaferri, T.L.; Jansen, M.; Horz, H.P. Fighting Pathogenic Bacteria on Two Fronts: Phages and Antibiotics as Combined Strategy. Front. Cell. Infect. Microbiol. 2019, 9, 22. [CrossRef] [PubMed]

22. Morrisette, T.; Kebriaei, R.; Lev, K.L.; Morales, S.; Rybak, M.J. Bacteriophage Therapeutics: A Primer for Clinicians on PhageAntibiotic Combinations. Pharmacotherapy 2020, 40, 153-168. [CrossRef]

23. Kortright, K.E.; Chan, B.K.; Koff, J.L.; Turner, P.E. Phage Therapy: A Renewed Approach to Combat Antibiotic-Resistant Bacteria. Cell Host Microbe 2019, 25, 219-232. [CrossRef] [PubMed]

24. Smith, K.P.; Kirby, J.E. The Inoculum Effect in the Era of Multidrug Resistance: Minor Differences in Inoculum Have Dramatic Effect on Mic Determination. Antimicrob. Agents Chemother. 2018, 62, e00433-18. [CrossRef]

25. Kilcher, S.; Loessner, M.J. Engineering Bacteriophages as Versatile Biologics. Trends Microbiol. 2019, 27, 355-367. [CrossRef] [PubMed]

26. Monteiro, R.; Pires, D.P.; Costa, A.R.; Azeredo, J. Phage Therapy: Going Temperate? Trends Microbiol. 2019, 27, 368-378. [CrossRef] 
27. Liu, C.G.; Green, S.I.; Min, L.; Clark, J.R.; Salazar, K.C.; Terwilliger, A.L.; Kaplan, H.B.; Trautner, B.W.; Ramig, R.F.; Maresso, A.W. Phage-Antibiotic Synergy is Driven by a Unique Combination of Antibacterial Mechanism of Action and Stoichiometry. $m$ Bio 2020, 11, e01462-20. [CrossRef] [PubMed]

28. Ronayne, E.A.; Wan, Y.C.; Boudreau, B.A.; Landick, R.; Cox, M.M. P1 Ref Endonuclease: A Molecular Mechanism for PhageEnhanced Antibiotic Lethality. PLoS Genet. 2016, 12, e1005797. [CrossRef]

29. Jo, A.; Kim, J.; Ding, T.; Ahn, J. Role of Phage-Antibiotic Combination in Reducing Antibiotic Resistance in Staphylococcus Aureus. Food Sci. Biotechnol. 2016, 25, 1211-1215. [CrossRef]

30. Kamal, F.; Dennis, J.J. Burkholderia Cepacia Complex Phage-Antibiotic Synergy (Pas): Antibiotics Stimulate Lytic Phage Activity. Appl. Environ. Microbiol. 2015, 81, 1132-1138. [CrossRef]

31. Uchiyama, J.; Shigehisa, R.; Nasukawa, T.; Mizukami, K.; Takemura-Uchiyama, I.; Ujihara, T.; Murakami, H.; Imanishi, I.; Nishifuji, K.; Sakaguchi, M.; et al. Piperacillin and Ceftazidime Produce the Strongest Synergistic Phage-Antibiotic Effect in Pseudomonas Aeruginosa. Arch. Virol. 2018, 163, 1941-1948. [CrossRef]

32. Knezevic, P.; Curcin, S.; Aleksic, V.; Petrusic, M.; Vlaski, L. Phage-Antibiotic Synergism: A Possible Approach to Combatting Pseudomonas Aeruginosa. Res. Microbiol. 2013, 164, 55-60. [CrossRef] [PubMed]

33. Bedi, M.S.; Verma, V.; Chhibber, S. Amoxicillin and Specific Bacteriophage Can be Used Together for Eradication of Biofilm of Klebsiella Pneumoniae B5055. World J. Microbiol. Biotechnol. 2009, 25, 1145-1151. [CrossRef]

34. Jo, A.; Ding, T.; Ahn, J. Synergistic Antimicrobial Activity of Bacteriophages and Antibiotics against Staphylococcus Aureus. Food Sci. Biotechnol. 2016, 25, 935-940. [CrossRef] [PubMed]

35. Kebriaei, R.; Lev, K.; Morrisette, T.; Stamper, K.C.; Abdul-Mutakabbir, J.C.; Lehman, S.M.; Morales, S.; Rybak, M.J. BacteriophageAntibiotic Combination Strategy: An Alternative against Methicillin-Resistant Phenotypes of Staphylococcus Aureus. Antimicrob. Agents Chemother. 2020, 64, e00066-18. [CrossRef]

36. Kim, M.; Jo, Y.; Hwang, Y.J.; Hong, H.W.; Hong, S.S.; Park, K.; Myung, H. Phage-Antibiotic Synergy Via Delayed Lysis. Appl. Environ. Microbiol. 2018, 84, e02085-18. [CrossRef]

37. Kolenda, C.; Josse, J.; Medina, M.; Fevre, C.; Lustig, S.; Ferry, T.; Laurent, F. Evaluation of the Activity of a Combination of Three Bacteriophages Alone or in Association with Antibiotics on Staphylococcus Aureus Embedded in Biofilm or Internalized in Osteoblasts. Antimicrob. Agents Chemother. 2020, 64, e02231-19. [CrossRef]

38. Kumaran, D.; Taha, M.; Yi, Q.; Ramirez-Arcos, S.; Diallo, J.S.; Carli, A.; Abdelbary, H. Does Treatment Order Matter? Investigating the Ability of Bacteriophage to Augment Antibiotic Activity against Staphylococcus Aureus Biofilms. Front. Microbiol. 2018, 9 , 127. [CrossRef]

39. Lebeaux, D.; Leflon-Guibout, V.; Ghigo, J.M.; Beloin, C. In Vitro Activity of Gentamicin, Vancomycin or Amikacin Combined with Edta or L-Arginine as Lock Therapy against a Wide Spectrum of Biofilm-Forming Clinical Strains Isolated from Catheter-Related Infections. J. Antimicrob. Chemother. 2015, 70, 1704-1712. [CrossRef]

40. Teng, T.; Li, Q.; Liu, Z.; Li, X.; Liu, Z.; Liu, H.; Liu, F.; Xie, L.; Wang, H.; Zhang, L.; et al. Characterization and Genome Analysis of Novel Klebsiella Phage Henu1 with Lytic Activity against Clinical Strains of Klebsiella Pneumoniae. Arch. Virol. 2019, 164, 2389-2393. [CrossRef]

41. Deghorain, M.; Bobay, L.M.; Smeesters, P.R.; Bousbata, S.; Vermeersch, M.; Perez-Morga, D.; Dreze, P.A.; Rocha, E.P.; Touchon, M.; Van Melderen, L. Characterization of Novel Phages Isolated in Coagulase-Negative Staphylococci Reveals Evolutionary Relationships with Staphylococcus Aureus Phages. J. Bacteriol. 2012, 194, 5829-5839. [CrossRef] [PubMed]

42. Xia, G.; Wolz, C. Phages of Staphylococcus Aureus and Their Impact on Host Evolution. Infect. Genet. Evol. 2014, $21,593-601$. [CrossRef]

43. Lubowska, N.; Grygorcewicz, B.; Kosznik-Kwasnicka, K.; Zauszkiewicz-Pawlak, A.; Wegrzyn, A.; Dolegowska, B.; Piechowicz, L. Characterization of the Three New Kayviruses and Their Lytic Activity Against Multidrug-Resistant Staphylococcus Aureus. Microorganisms 2019, 7, 471. [CrossRef]

44. Moller, A.G.; Lindsay, J.A.; Read, T.D. Determinants of Phage Host Range in Staphylococcus Species. Appl. Environ. Microbiol. 2019, 85, e00209-19. [CrossRef]

45. Botka, T.; Pantǔček, R.; Mašlaňová, I.; Benešík, M.; Petráš, P.; Růžičková, V.; Havlíčková, P.; Varga, M.; Žemličková, H.; Koláčková, I.; et al. Lytic and Genomic Properties of Spontaneous Host-Range Kayvirus Mutants Prove Their Suitability for Upgrading Phage Therapeutics against Staphylococci. Sci. Rep. 2019, 9, 5475. [CrossRef] [PubMed]

46. Adriaenssens, E.M.; Wittmann, J.; Kuhn, J.H.; Turner, D.; Sullivan, M.B.; Dutilh, B.E.; Jang, H.B.; Van Zyl, L.J.; Klumpp, J.; Lobocka, M.; et al. Taxonomy of Prokaryotic Viruses: 2017 Update from the Ictv Bacterial and Archaeal Viruses Subcommittee. Arch. Virol. 2018, 163, 1125-1129. [CrossRef]

47. Fu, T.; Fan, X.; Long, Q.; Deng, W.; Song, J.; Huang, E. Comparative Analysis of Prophages in Streptococcus Mutans Genomes. PeerJ 2017, 5, e4057. [CrossRef]

48. Teng, T.; Zhang, G.; Fan, X.; Zhang, Z.; Zhang, L.; Wu, D.; Chen, S.; Li, Y.; Jin, J. Complete Genome Sequence Analysis of Ps2, A Novel T4-Like Bacteriophage That Infects Serratia Marcescens Clinical Isolates. Arch. Virol. 2018, 163, 1997-2000. [CrossRef]

49. Brown, K.L.; Sarkis, G.J.; Wadsworth, C.; Hatfull, G.F. Transcriptional Silencing by the Mycobacteriophage L5 Repressor. EMBO J. 1997, 16, 5914-5921. [CrossRef]

50. Zhou, Y.; Liang, Y.; Lynch, K.H.; Dennis, J.J.; Wishart, D.S. Phast: A Fast Phage Search Tool. Nucleic Acids Res. 2011, 39, W347-W352. [CrossRef] 
51. Arndt, D.; Grant, J.R.; Marcu, A.; Sajed, T.; Pon, A.; Liang, Y.; Wishart, D.S. Phaster: A Better, Faster Version of the Phast Phage Search Tool. Nucleic Acids Res. 2016, 44, W16-W21. [CrossRef] [PubMed]

52. Los, J.M.; Los, M.; Wegrzyn, A.; Wegrzyn, G. Hydrogen Peroxide-Mediated Induction of the Shiga Toxin-Converting Lambdoid Prophage St2-8624 in Escherichia Coli O157:H7. FEMS Immunol. Med. Microbiol. 2010, 58, 322-329. [CrossRef] [PubMed]

53. Filipiak, M.; Łoś, J.M.; Łoś, M. Efficiency of Induction of Shiga-Toxin Lambdoid Prophages in Escherichia Coli Due to Oxidative and Antibiotic Stress Depends on the Combination of Prophage and the Bacterial Strain. J. Appl. Genet. 2020, 61, 131-140. [CrossRef] [PubMed]

54. Loś, J.M.; Golec, P.; Wegrzyn, G.; Wegrzyn, A.; Loś, M. Simple Method for Plating Escherichia Coli Bacteriophages Forming very Small Plaques or No Plaques under Standard Conditions. Appl. Environ. Microbiol. 2008, 74, 5113-5120. [CrossRef]

55. Grygorcewicz, B.; Roszak, M.; Golec, P.; Sleboda-Taront, D.; Lubowska, N.; Gorska, M.; Jursa-Kulesza, J.; Rakoczy, R.; Wojciuk, B.; Dolegowska, B. Antibiotics Act With Vb_Abap_Agc01 Phage against Acinetobacter Baumannii in Human Heat-Inactivated Plasma Blood and Galleria Mellonella Models. Int. J. Mol. Sci. 2020, 21, 4390. [CrossRef] [PubMed]

56. Grygorcewicz, B.; Wojciuk, B.; Roszak, M.; Lubowska, N.; Blazejczak, P.; Jursa-Kulesza, J.; Rakoczy, R.; Masiuk, H.; Dolegowska, B. Environmental Phage-Based Cocktail and Antibiotic Combination Effects on Acinetobacter Baumannii Biofilm in a Human Urine Model. Microb. Drug Resist. 2021, 27, 25-35. [CrossRef]

57. Struk, M.; Grygorcewicz, B.; Nawrotek, P.; Augustyniak, A.; Konopacki, M.; Kordas, M.; Rakoczy, R. Enhancing Effect of 50 Hz Rotating Magnetic Field on Induction of Shiga Toxin-Converting Lambdoid Prophages. Microb. Pathog. 2017, 109, 4-7. [CrossRef] [PubMed]

58. Roach, D.R.; Leung, C.Y.; Henry, M.; Morello, E.; Singh, D.; Di Santo, J.P.; Weitz, J.S.; Debarbieux, L. Synergy Between The Host Immune System and Bacteriophage is Essential for Successful Phage Therapy against an Acute Respiratory Pathogen. Cell Host Microbe 2017, 22, 38-47. [CrossRef] [PubMed]

59. Van Belleghem, J.D.; Dabrowska, K.; Vaneechoutte, M.; Barr, J.J.; Bollyky, P.L. Interactions between Bacteriophage, Bacteria, and the Mammalian Immune System. Viruses 2018, 11, 10. [CrossRef]

60. Kaur, S.; Harjai, K.; Chhibber, S. Bacteriophage-Aided Intracellular Killing of Engulfed Methicillin-Resistant Staphylococcus Aureus (Mrsa) by Murine Macrophages. Appl. Microbiol. Biotechnol. 2014, 98, 4653-4661. [CrossRef]

61. Kaur, S.; Harjai, K.; Chhibber, S. In Vivo Assessment of Phage and Linezolid Based Implant Coatings for Treatment of Methicillin Resistant S. aureus (Mrsa) Mediated Orthopaedic Device Related Infections. PLoS ONE 2016, 11, e0157626. [CrossRef] [PubMed]

62. Tiwari, B.R.; Kim, S.; Rahman, M.; Kim, J. Antibacterial Efficacy of Lytic Pseudomonas Bacteriophage in Normal and Neutropenic Mice Models. J. Microbiol. 2011, 49, 994-999. [CrossRef]

63. Leung, C.Y.J.; Weitz, J.S. Modeling the Synergistic Elimination of Bacteria by Phage and the Innate Immune System. J. Theor. Biol. 2017, 429, 241-252. [CrossRef]

64. Pincus, N.B.; Reckhow, J.D.; Saleem, D.; Jammeh, M.L.; Datta, S.K.; Myles, I.A. Strain Specific Phage Treatment for Staphylococcus Aureus Infection is Influenced by Host Immunity and Site of Infection. PLoS ONE 2015, 10, e0124280. [CrossRef]

65. Albac, S.; Medina, M.; Labrousse, D.; Hayez, D.; Bonnot, D.; Anzala, N.; Laurent, F.; Ferry, T.; Dublanchet, A.; Chavanet, P.; et al. Efficacy of Bacteriophages in a Staphylococcus Aureus Nondiabetic or Diabetic Foot Infection Murine Model. Antimicrob. Agents Chemother. 2020, 64, e01870-19. [CrossRef]

66. Pajunen, M.; Kiljunen, S.; Skurnik, M. Bacteriophage Phiyeo3-12, Specific for Yersinia Enterocolitica Serotype O:3, is Related to Coliphages T3 And T7. J. Bacteriol. 2000, 182, 5114-5120. [CrossRef]

67. Serwer, P.; Hayes, S.J.; Thomas, J.A.; Griess, G.A.; Hardies, S.C. Rapid Determination of Genomic Dna Length for New Bacteriophages. Electrophoresis 2007, 28, 1896-1902. [CrossRef] [PubMed]

68. Dong, W.; Wu, D.; Li, G.; Wu, D.; Wang, Z. Next-Generation Sequencing from Bulked Segregant Analysis Identifies a Dwarfism Gene in Watermelon. Sci. Rep. 2018, 8, 2908. [CrossRef]

69. Zhang, X.; Wang, Y.; Li, S.; An, X.; Pei, G.; Huang, Y.; Fan, H.; Mi, Z.; Zhang, Z.; Wang, W.; et al. A Novel Termini Analysis Theory Using Hts Data Alone for the Identification of Enterococcus Phage Ef4-Like Genome Termini. BMC Genom. 2015, 16, 414. [CrossRef]

70. Li, Y.; Zhang, W. Isolation and Characterization of Microsatellite Markers for Jasminum Sambac (Oleaceae) Using Illumina Shotgun Sequencing. Appl. Plant Sci. 2015, 3, 1500063. [CrossRef] [PubMed]

71. Borodovsky, M.; Mills, R.; Besemer, J.; Lomsadze, A. Prokaryotic Gene Prediction Using Genemark and Genemark.Hmm. Curr. Protoc. Bioinform. 2003, 1, 4-5. [CrossRef] [PubMed]

72. Conant, G.C.; Wolfe, K.H. Genomevx: Simple Web-Based Creation of Editable Circular Chromosome Maps. Bioinformatics 2008, 24, 861-862. [CrossRef] [PubMed]

73. Mirzaei, M.K.; Nilsson, A.S. Isolation of Phages for Phage Therapy: A Comparison of Spot Tests and Efficiency of Plating Analyses for Determination of Host Range and Efficacy. PLoS ONE 2015, 10, e0118557. [CrossRef] [PubMed]

74. Chang, Y.; Shin, H.; Lee, J.H.; Park, C.J.; Paik, S.Y.; Ryu, S. Isolation and Genome Characterization of the Virulent Staphylococcus Aureus Bacteriophage Sa97. Viruses 2015, 7, 5225-5242. [CrossRef] 